\title{
Compared Efficiency of Abilities to Steer Learning Situations by Two Categories of Sport and Physical Education Teachers Having Different Levels of Academic Qualification
}

\author{
Maher Mrayeh, Aymen Hawani, Aymen Mechrgui \\ Higher Institute of Sport and Physical Education of Ksar Said, Tunis, Tunisia \\ Email: mrayeh.meher@hotmail.fr, hawani.aymen@yahoo.com, mechrgui.aymen@gmail.com
}

Received 13 July 2014; revised 14 August 2014; accepted 22 August 2014

Copyright (C) 2014 by authors and Scientific Research Publishing Inc.

This work is licensed under the Creative Commons Attribution International License (CC BY). http://creativecommons.org/licenses/by/4.0/

(c) $\underset{\mathrm{EY}}{0}$ Open Access

\section{Abstract}

The aims of this study is to make an obvious fact about the impact of academic qualification of sport teachers on degree of abilities to steer learning situations. 20 teachers working in 6 scholar establishments and having a professional experience between 7 and 10 years were participated in this study. They are divided according to the level of their academic qualification. The experimental task is to make video and sound recordings of teachers sessions provided by all chosen pedagogical frameworks. The evaluation will focus on different indicators of professional skill of driving situations teachings. In total, 40 sessions randomly selected were filmed. The results obtained allowed us to infer that the piloting skill teaching situations is moderately mastered by all teachers observed regardless of their level of academic qualification. However, it should be mentioned that there is a little difference in favor of teachers maîtrisards. It should also be noted that difficulties were identified in two categories of teachers observed (master and master's degree). Difficulties in indicators related to the explanation of the task to be performed and the level of precision of resources to which students have access to perform learning. Nevertheless, it should be noted that teachers controlled more or less the organization of groups and compliance planning. Finally, this study showd that masters teachers are more skilled at the precision of resources, group organization and encouragement of students. However, the explanation of the task to be performed and the respect of planning are indifferent to the variable level of qualification.

\section{Keywords}

Compared Efficiency, Abilities to Steer, Learning Situations, Physical Education Teachers, Level of 


\section{Academic Qualification}

\section{Introduction}

The professional training is a process that has a practical purpose. This purpose is characterized by the construction and development of professional skills useful for teaching practice. This training is specified by the development of teaching skills, which emphasizes the importance of knowledge to teach in addition to the mastery of knowledge to teach Altet (1995). For their part, Altet, Paquay and Perrenoud (2002) enhance that the training recognizes the specificity of teaching practice as a labor of interaction teaching situation finalized. Teaching is a complex profession, which can be defined in its complexity in terms of tasks, methods or planned a priori techniques.

Indeed, the difficulty of the intervention in sport and physical education (SPE) is explained by the fact that it takes place in professional exchange situations and interactions with different learners, characterized by unpredictability in the management of events, multiplicity of decision-making, and the simultaneity of tasks Perrenoud (1993, 1994a, 1994b). In these professional situations, Tardif (1993) and later Paquay (1996) suggest that the model of rational teacher shall implement different types of action thus covering the traditional act, emotional, normative, strategic, the dramatic, expressive and the communicational one.

So we can consider that the teacher is taken to guide a learning process from the beginning to the end using a set of professional actions allowing him to create a classroom climate conducive to learning (Altet, 1998). Thus, the teaching profession is at the interface of two types of identity: identity directly related to the work for the class and in the classroom Theureau (2000). This leads us to identify the physical education teacher must have a power of intervention for her good behavior in class and ensure an effective learning process with all levels of students.

However, it should be noted that the primary school teachers, college and secondary school professors ensure the business unit beyond the particularities of each level of education. Now, the training of teachers in Tunisia is based on a competency framework implicitly mentioned in the academic and devices through a number of training units. They relate to knowledge, skills as well as basic and professional attitudes necessary to perform the tasks assigned.

Nevertheless, it is noteworthy that handling a multitude of teaching situations with all possible constraints requires continuous attention and continuous process from the teacher (Vergnaud, 1993). Twelve teaching professional practices and trainings for careers in education and training barriers were identified by a number of researchers, such as Berthier and Ubaldi (2006). These researchers have tried to describe the sensitive elements which hinder the ownership of institutional areas, axiological, instructional, teaching and professional gestures of action.

In fact, these obstacles are represented by the decision-making, values, knowledge involved, actions, space/ time, issues of communication, personal theory of action, distance, planning, authority, interdisciplinarity, and individual/collective. Moreover, the issue of training is designed to describe the tension and sore point accompanying empirical facets, technical, theoretical of the didactic impediment. Indeed, in the dynamics of the professional didactic obstacles and according to the lived situations, professional identity will build and shape. If their awareness in work practice analysis does not guarantee a change in the subject of his actions, it nonetheless constitutes a major and decisive moment in the construction and training of professional identity that will enroll in a professional community and at the same time manifest its uniqueness and personal style. To conclude this introduction, it is imperative to note that the objective of this study is to highlight the impact of the qualification of sport and physical education teachers on the quality of their performance with respect to the degree of mastery of the competency steering teaching-learning situations especially as relates to the explanation of the driving task at hand, the accuracy of the resources necessary to accomplish the required engine performance, organizing groups and compliance planning.

We also fixed as aims to answer the questions of the following searches:

- What is the level of mastery of the competency steering learning situations among physical education teachers? 
- Is there a relationship between the type of degree held and the level of mastery of the competency steering learning situations?

\section{Methodology}

\subsection{Objective Research}

The objective of this study is to highlight the impact of the qualification of sport and physical education teachers on the quality of their performance with respect to the degree of mastery of the competency steering teachinglearning situations especially as relates to the explanation of the driving task at hand, the accuracy of the resources necessary to accomplish the required engine performance, organizing groups and compliance planning.

\subsection{Experimental Sample}

Our sample consists of 20 teachers working in 6 scholar establishments in the city of big Tunisia and having professional experience of 7 to 10 years was participated in this study. Their ages range between 32 and 35 years. The sample is divided according to the following variable: levels of academic qualification. The performance evaluation of selected pedagogical frameworks is done with classes 9th base year with an average of 34 students per class. The population of teachers was observed and evaluated during the physical education activities that have no link with their origins sports specialties (see Table 1).

\subsection{Experimental Procedures}

The experimental task is to make video and sound recordings of tge sessions of sport and physical education (SPE) provided by all the chosen teachers. The observation and evaluation will focus on different indicators of the competence of driving situations teachings. In total, 40 sessions of SPE chosen at random are filmed. Each of these teachers has been observed during two sessions.

Sessions observed are filmed with a digital camera, Sony Cyber Shot 14.1 megapixels. Filming begins at the first interaction of the teacher with his students. It is concluded when the last interaction is complete. All the observed sessions lasts between 50 and 55 minutes. At the first presence of researcher in each class, the teacher and the researcher justify the presence of the observer and the camera by explaining to students that it is a collaboration between young teachers for training in as a new teacher. The insistence is not carried about their behavior and consequences of their schooling.

The filming takes place in the same way on the all sites of research. It is provided by a mobile camera, focused on the teacher and held by the researcher or perhaps put to him at different times of each session. The mobility of the camera is to monitor to follow the activity of the teacher through the pivots and zooms. The pivots are used to track his movements when the teacher leaves the plane of the camera. Zooms are to identify more clearly the teacher actions when he is away from the camera. In order to not interfere with the conduct of lessons and can cover a wide angle of educational space, the recording made from an eccentric position.

The researcher is always taking place in the corner of the gym, the field or the gym, usually sitting against a wall, behind a table on which rests the camera. Furthermore, teachers are equipped with a lavalier microphone connected wirelessly to the camera and thereby have, on the same tape, video recordings relating to the activity of the teacher in the midst of students, and audio recordings referring to verbal interactions between teacher and students. All these audio and video recordings have led us to the final archive 40 strips about an hour. From these bands, the same researcher who has filled records 40 grids observations.

Table 1. Characteristics of the study sample.

\begin{tabular}{cccc}
\hline & & Age (years) & Level of expertise (years) \\
\hline \multirow{2}{*}{ Entire study population } & $\delta$ & 34.52 & 8.32 \\
& Min & 1.77 & 1.21 \\
& Max & 32.12 & 7.45 \\
& & 35.47 & 10.26 \\
\hline
\end{tabular}




\subsection{The Observation Grid}

Control of pedagogical situation means the ability to establish risk-taking uncertainties and constraints and to mark students learning way. It thus implies that the teacher gives a direction, paving the way, landscape obstacles and landmarks, redirects and sometimes models approaches and detours to take students. Far from restricting the function of command or management time and resources in the classroom, this jurisdiction includes the discernment which guides the teacher's attention to the signs of an imbalance in students' conceptions, which indexes the warning to trigger and develop approaches to learning to create new balances Lebrun and Wood (2002).

So in choosing the means to collect the necessary study that we conducted we opted for the choice of video recordings that could bring every detail and provided a workable at all times memory. To carry out this research we relied on a didactic support, we crafted from some grids specialists (Sarthou, J. Actio 2003; Récopé 2001; Bouthier, 1986) to facilitate note taking and help limit the parameters to be observed. In order to evaluate the competence of driving situations Teaching in Sport and Physical Education, we have identified the following five skills components of competence steering (Roux-Perez, 2005):

1) The explanation of the task at hand: Uses a nice and enthusiastic tone, demonstration uses gestures, trying to maintain eye gaze with students, solicits students' attention, repeat elements misunderstood, checks understanding students and uses clear language;

2) Accuracy of resources: Uses music, uses media, uses the educational material (studs, spikes, balls, lattes...), uses the stopwatch and whistle and uses the appropriate space;

3) The organization of groups: Demonstrated availability to students, the tag field, precise directions, circulates between groups, redirecting students and fixed pins;

4) Encouragement: Encourages students to correct itself, encourages students to help each other, avoids negative reviews, raises the interaction between students, stimulates students (even lower), encourages students by asking them personally and gives feeds back positive (well, yes, Voila...);

5) Respect for planning: Respects the cyclic program, the fixed number of passes and repeat, respects the time for each situation and adjusts the meeting in relation to unforeseen (number of groups, land availability, climate...);

6) Statistical Procedures: To analyze the data, we chose the statistical tools most frequently appropriate to the field of physical and sporting activities. We used the statistical software SPSS 16.0 (2006). The statistical evaluation of the data collected was performed using descriptive statistics (we used the mean, standard deviation, minimum and maximum values), and comparative statistics (we used T single student).

\section{Result and Interpretation}

\subsection{Assessment of Competence in General Steering}

1) Degree of mastery of the competency steering learning situations.

The use of data in Table 2 allowed us to distinguish the degree of mastery of general professional competence concerning pilotage of learning situations proves moderately mastered by SPE teachers studied $(P<1.25)$.

2) Determining the overall level of mastery of the competency control depending on the level of qualification of SPE teachers.

The use of statistical values in Table 3 on the effect of the variable level of qualification of teachers competence steering learning situations in general has allowed us to infer that PE teachers (E1) mastered better control the competence of learning situations that PE teachers $(E 2)(P<0.002)$.

\subsection{Evaluation of Component Skills Piloting Learning Situations}

\subsubsection{The Component of Competence Regarding the Explanation of the Task to Execute}

1) Evaluation of the explanation of the task to perform general.

Table 2. Degree of control of the competency steering.

\begin{tabular}{|c|c|c|c|c|}
\hline & Average $\pm \mathrm{e}-\mathrm{t}$ & $\begin{array}{c}\text { Extended } \\
\text { (Min-Max) }\end{array}$ & $\begin{array}{l}\text { Compared with the standard } \\
\text { value }\end{array}$ & Degree of mastery \\
\hline Competence steering learning situations & $3.90 \pm 2.68$ & $3.47-4.39$ & $\begin{array}{c}P<1.25 \\
\text { (Not significant) }\end{array}$ & Moderately mastered \\
\hline
\end{tabular}


Use the results of Table 4 allowed us to conclude that the explanation of the task to be performed, as a parameter within the jurisdiction steering in different sessions observed SPE is not mastered by teachers studied $(P<0.002$ and $3.67<4)$.

2) Evaluation of the explanation of the task to be performed depending on the skill level of PE teachers.

The use of statistical values in Table 5 on the effect of the variable level of qualification of teachers on teaching skills on the explanation of the task at hand has allowed us to distinguish the degree of mastery of the latter does not matter whatever the academic graduation.

\subsubsection{Evaluation of Different Indicators for Explaining the Task to be Executed}

Analysis of the data indicated above in Table 6 and are related to indicators on the explanation of the task to be performed we concluded that four out of seven indicators are moderately mastered. We note respectively the indicator on the use of a pleasant and enthusiastic tone, use of demonstration gestures, maintaining eye gaze with students and soliciting students' attention during sequences teaching. However, it should be noted that the repetition of misunderstood, verification of student understanding, and the use of plain language are few indicators mastered by all educational settings observed.

1) Evaluation of the quality of ownership of different indicators for the explanation of the task to be performed depending on the level of qualification.

The analysis of the above-listed in Table 7 and data on indicators that are on the explanation of the task to be

Table 3. Degree of mastery of the skill of driving and skill level.

\begin{tabular}{ccc} 
& Average $\pm \mathrm{e}-\mathrm{t}$ & Comparison of mean \\
\hline Teacher (E2) & $3.74 \pm 0.19$ & \\
Teacher (E1) & $4.09 \pm 0.21$ & $P<0.002$ (Significant) \\
\hline
\end{tabular}

Table 4. Quality of component jurisdiction in the explanation of the task to execute all teachers studied.

\begin{tabular}{ccccc}
\hline & Average \pm e-t & Extended (Min-Max) & Compared with the standard value & Degree of control \\
\hline $\begin{array}{c}\text { Competence of the explanation of } \\
\text { the task performed in general }\end{array}$ & $3.67 \pm 0.40$ & $3.14-4.86$ & $P<0.002$ (Significant) & Little mastered \\
\hline
\end{tabular}

Table 5. Quality of component jurisdiction in the explanation of the task to be performed depending on the level of qua- lification.

\begin{tabular}{ccc}
\hline & Average \pm e-t & Comparison of mean \\
\hline Teacher (E2) & $3.55 \pm 0.29$ & \\
Teacher (E1) & $3.82 \pm 0.47$ & $P<0.14$ (Not significant) \\
\hline
\end{tabular}

Table 6. Quality indicators for explaining the task to be executed.

\begin{tabular}{|c|c|c|c|c|}
\hline & Average $\pm \mathrm{e}-\mathrm{t}$ & Etendu (Min-Max) & $\begin{array}{l}\text { Compared with the } \\
\text { standard value }\end{array}$ & $\begin{array}{l}\text { Level of mastery of the } \\
\text { indicator }\end{array}$ \\
\hline $\begin{array}{l}\text { Use a pleasant tone and } \\
\text { enthusiastic }\end{array}$ & $4.15 \pm 1.22$ & $2-6$ & $P<0.59 \mathrm{NS}$ & Mastered moderately \\
\hline Uses gesture demonstration & $4.40 \pm 1.09$ & $3-6$ & $P<0.11 \mathrm{NS}$ & Mastered moderately \\
\hline $\begin{array}{c}\text { Seeks to maintain eye gaze with } \\
\text { students }\end{array}$ & $4.40 \pm 1.19$ & $2-6$ & $P<0.053 \mathrm{NS}$ & Mastered moderately \\
\hline Solicits students' attention & $3.90 \pm 0.96$ & $3-6$ & $P<0.64 \mathrm{NS}$ & Mastered moderately \\
\hline $\begin{array}{l}\text { Repeat elements } \\
\text { misunderstood }\end{array}$ & $3.40 \pm 0.88$ & $2-5$ & $P<0.007^{* *}$ & Few mastered \\
\hline Checks student understanding & $3.25 \pm 0.96$ & $2-5$ & $P=0.003^{* *}$ & Few mastered \\
\hline Use plain language & $3.20 \pm 0.69$ & $2-4$ & $P<0.001^{* * *}$ & Few mastered \\
\hline
\end{tabular}

$P$ : Probability; NS: Not significant; $P<0.05 ;{ }^{* *} P<0.01 ;{ }^{* * *} P<0.001$. 
performed depending on the skill level of PE teachers, allow to say that among the seven indicators explanation of the task to execute six are indifferent level qualification PE teachers. We note respectively the indicator on the use of a pleasant and enthusiastic tone, the use of gestural demonstration, soliciting the attention of students, repetition of elements misunderstood, checking the understanding of the student, as well as the use of plain language. By cons we found that PE teachers (E1) better mastered the fact Seek to maintain eye gaze with students and teachers of SPE (E2).

\subsection{Component of Competence Regarding the Accuracy of the Resources}

\subsubsection{Assessment of the Accuracy of the Overall Resources}

1) Evaluation of the accuracy of the resources of all teachers surveyed.

The analysis of the statistical values shown in Table 8 shows that PE teachers reported experiencing difficulties with regard to the accuracy of the resources to which students have access to perform scheduled and desired learning.

2) Assessment of the accuracy of the resources according to the skill level.

Visualization of statistical values in Table 9 on the effect of varying skill levels of teachers competence for the accuracy of the resources allowed us to infer that PE teachers (E1) mastered it better that PE teachers (E2).

\subsubsection{Evaluation of the Quality of Ownership of Various Indicators of the Accuracy of the} Resources

Reading in Table 10, we concluded that the majority of teachers observed have mastered the use of a space that responds to the number of students in their classes and the nature of the activity addressed. The use of media or music as teaching resources appear to be two components of precision low HGV resources. However, it should be noted that the use of educational material, and the use of the whistle and stopwatch are moderately mastered.

1) Evaluation of the quality of ownership of different indicators as to the accuracy of resources depending on the level of qualification of PE teachers.

Table 7. Quality of the indicators relating to the explanation of the task to be performed depending on the level of qua- lification.

\begin{tabular}{|c|c|c|c|}
\hline \multicolumn{4}{|c|}{ Average $\pm \mathrm{e}-\mathrm{t}$} \\
\hline Indicators & Teacher (E2) & Teacher (E1) & Comparison of mean \\
\hline Using a pleasant and enthusiastic tone & $4.09 \pm 1.30$ & $4.22 \pm 1.20$ & $P<0.81 \mathrm{NS}$ \\
\hline Using gestures demonstration & $4.09 \pm 0.94$ & $4.77 \pm 1.20$ & $P<0.16 \mathrm{NS}$ \\
\hline The fact of trying to maintain eye gaze with students & $2.90 \pm 1.04$ & $4.11 \pm 1.05$ & $P<0.02^{*}$ \\
\hline Solicitation of students' attention & $3.72 \pm 0.90$ & $4.11 \pm 1.05$ & $P<0.39$ NS \\
\hline Repeating elements misunderstood & $3.63 \pm 0.92$ & $3.11 \pm 0.78$ & $P<0.19$ NS \\
\hline Verification of student understanding & $3.27 \pm 1$ & $3.22 \pm 0.97$ & $P<0.91 \mathrm{NS}$ \\
\hline L'utilisation d'un langage clair & $3.18 \pm 0.60$ & $3.22 \pm 0.83$ & $P<0.90 \mathrm{NS}$ \\
\hline
\end{tabular}

NS: Not significant; ${ }^{*} P<0.05 ; P<0.01 ; P<0.001$.

Table 8. Quality of the general precision resources.

\begin{tabular}{lcccc}
\hline & Average \pm e-t & $\begin{array}{c}\text { Extended } \\
\text { (Min-Max) }\end{array}$ & $\begin{array}{c}\text { Compared with the } \\
\text { standard value }\end{array}$ & $\begin{array}{c}\text { Level of mastery of the } \\
\text { indicator }\end{array}$ \\
\hline Quality of the general precision resources & $3.53 \pm 0.31$ & $3-4.20$ & $P<0.001$ (Significant) \\
\hline
\end{tabular}

Table 9. Competence regarding the accuracy of the resources based on the level of academic qualification.

\begin{tabular}{ccc}
\hline & Average \pm e-t & Comparison of mean \\
\hline Teacher (E2) & $3.40 \pm 0.29$ & $P<0.04$ (Significant) \\
Teacher (E1) & $3.68 \pm 0.28$ &
\end{tabular}


According to the statistical values in Table 11 on the effect of the variable level of qualification of teachers on five indicators of teacher competence as to the accuracy of the resources we can deduce that this variable has no effect five indicators.

\subsection{Component of Competence on the Organization of Groups}

\subsubsection{Evaluation of Group Organization in General}

Statistical analysis values given in Table 12 shows that the SPE teachers observed moderately mastered competence for the organization of groups of students during the teaching-learning process.

1) Evaluation of the organization of groups based on skill level.

The use of Table 13 on the effect of the variable level of qualification of teachers on teaching skills on the organization of groups allowed us to infer that PE teachers (E1) mastered it better than teachers SPE (E2).

Table 10. Quality indicators for the accuracy of the resources.

\begin{tabular}{|c|c|c|c|c|}
\hline & $\begin{array}{l}\text { Average } \pm \\
\text { e-t }\end{array}$ & $\begin{array}{c}\text { Extended } \\
\text { (Min-Max) }\end{array}$ & $\begin{array}{l}\text { Compared with the } \\
\text { standard value }\end{array}$ & $\begin{array}{l}\text { Level of mastery of } \\
\text { the indicator }\end{array}$ \\
\hline Uses musique & $2.30 \pm 0.73$ & $2-4$ & $P=0.001^{* * *}$ & Little mastered \\
\hline Uses media & $2.30 \pm 0.47$ & $2-3$ & $P=0.001^{* * *}$ & Little mastered \\
\hline Using educational material (studs, spikes, balls, lattes...) & $4.25 \pm 1.16$ & $2-6$ & $P=0.43 \mathrm{NS}$ & Moderately mastered \\
\hline Use the stopwatch and whistle & $3.80 \pm 1.19$ & $2-6$ & $P=0.46 \mathrm{NS}$ & Moderately mastered \\
\hline $\begin{array}{l}\text { Using a space that responds to the number of students } \\
\text { and the nature of the activity }\end{array}$ & $5.00 \pm 0.72$ & $4-6$ & $P=0.001^{* * *}$ & Well mastered \\
\hline
\end{tabular}

NS: Not significant; $P<0.05 ; P<0.01 ;{ }^{* * *} P<0.001$.

Table 11. Quality precision of resources based on the level of qualification.

\begin{tabular}{|c|c|c|c|}
\hline \multicolumn{4}{|c|}{ Average $\pm \mathrm{e}-\mathrm{t}$} \\
\hline Indicators & Teachers (E2) & Teachers (E1) & Comparison of mean \\
\hline Uses musique & $2.36 \pm 0.80$ & $2.22 \pm 0.66$ & $P<0.67 \mathrm{NS}$ \\
\hline Uses media & $2.27 \pm 0.46$ & $2.33 \pm 0.50$ & $P<0.78$ NS \\
\hline Using educational material (studs, spikes, balls, lattes...) & $3.81 \pm 1.07$ & $4.77 \pm 1.09$ & $P<0.06 \mathrm{NS}$ \\
\hline Use the stopwatch and whistle & $3.45 \pm 1.21$ & $4.22 \pm 1.09$ & $P<0.15 \mathrm{NS}$ \\
\hline $\begin{array}{l}\text { Using a space that responds to the number of students and the nature } \\
\text { of the activity }\end{array}$ & $5.09 \pm 0.70$ & $4.88 \pm 0.78$ & $P<0.55 \mathrm{NS}$ \\
\hline
\end{tabular}

NS: Not significant, $P<0.05, P<0.01, P<0.001$.

Table 12. Quality of competence on the part of organizing groups of all teachers surveyed.

\begin{tabular}{lcccc}
\hline & Average $\pm \mathrm{e}-\mathrm{t}$ & Extended (Min-Max) & $\begin{array}{c}\text { Compared with the standard } \\
\text { value }\end{array}$ & $\begin{array}{c}\text { Level of mastery of the } \\
\text { indicator }\end{array}$ \\
\hline The organization groups & $4.12 \pm 0.53$ & $3.33-5.17$ & $P=0.30$ (Not significant) \\
\hline
\end{tabular}

Table 13. Quality of component jurisdiction over the organization of the groups according to the level of qualification.

\begin{tabular}{ccc}
\hline & Average $\pm \mathrm{e}-\mathrm{t}$ & Comparison of mean \\
\hline Teacher (E2) & $3.90 \pm 0.40$ & $P=0.04$ (Significant) \\
Teacher (E1) & $4.38 \pm 0.57$ & \\
\hline
\end{tabular}

\subsubsection{Evaluation of the Quality of Ownership of Various Indicators Relating to the Organization of Groups}

The use Table 14 has allowed us to conclude that the majority of teachers have mastered the observed move- 
ment between groups. By cons they have mastered the medium made to show availability to students, markup field, the accuracy of directions, redirecting students and setting benchmarks.

1) Evaluation of the quality of ownership of various indicators relating to the organization of groups according to skill level of PE teachers.

The analysis of the above-indicated in Table 15 and data on indicators that are on the organization of groups according to skill level of PE teachers, we concluded that among the six indicators the organization of five groups are indifferent level qualification PE teachers. We note respectively represented by the indicator made exercise available to students, the traffic between the groups, the accuracy of the directions of the shifts of students, as well as setting benchmarks. However, we reported that SPE teachers (E1) better mastered markup field that PE teachers (E2).

\subsection{Component of Jurisdiction in Encouraging Pupils}

\subsubsection{Evaluation of Encouraging Students in General}

1) Evaluation of encouraging students of all teachers surveyed.

Statistical analysis values given in Table 16 shows that PE teachers observed develop a positive motivational potential influencing the educational intervention and manifested by encouraging students.

2) Evaluation of encouraging pupils to the level of qualification of PE teachers studied.

The use of statistical values in Table 17 on the effect of varying skill levels of teachers on teaching skills on encouraging students allowed us to infer that SPE teachers maîtrisards undertake too positively than their counterparts in skill level (bac +2).

\subsubsection{Evaluation of the Quality of Ownership of Different Indicators on Encouraging Pupils}

1) The quality of ownership of different indicators on encouraging students to all teachers.

The statistics in Table 18 values have allowed us to conclude that the majority of teachers observed have

Table 14. Quality indicators for the organization of groups of all teachers surveyed.

\begin{tabular}{ccccc}
\hline & Average \pm e-t & Extended (Min-Max) & $\begin{array}{c}\text { Compared with the } \\
\text { standard value }\end{array}$ & $\begin{array}{c}\text { Level of mastery of the } \\
\text { indicator }\end{array}$ \\
\hline Demonstrates availability to students & $3.55 \pm 0.94$ & $2-6$ & $P=0.46 \mathrm{NS}$ & Moderately mastered \\
Tag field & $4.55 \pm 1.14$ & $2-6$ & $P=0.45 \mathrm{NS}$ & Moderately mastered \\
Precise directions & $4.40 \pm 0.99$ & $3-6$ & $P=0.88 \mathrm{NS}$ & Moderately mastered \\
Circulates between groups & $4.60 \pm 1.14$ & $2-6$ & $P=0.03^{*}$ & Well mastered \\
Redirects students & $3.70 \pm 1.08$ & $2-5$ & $P=0.23 \mathrm{NS}$ & Moderately mastered \\
Fixed pins & $3.95 \pm 1.14$ & $2-5$ & $P=0.84 \mathrm{NS}$ & Moderately mastered \\
\hline
\end{tabular}

NS: Not significant, ${ }^{*} P<0.05, P<0.01, P<0.001$.

Table 15. Quality indicators of the competence of the organization of groups based on skill level.

\begin{tabular}{|c|c|c|c|}
\hline \multicolumn{4}{|c|}{ Average $\pm \mathrm{e}-\mathrm{t}$} \\
\hline Indicators & Teacher (E2) & Teacher (E1) & Comparison of mean \\
\hline The making himself available to students & $3.54 \pm 0.82$ & $3.55 \pm 1.13$ & $P<0.98$ NS \\
\hline Tag field & $3.90 \pm 1.04$ & $5.33 \pm 0.70$ & $P<0.003^{* *}$ \\
\hline Precise directions & $4.09 \pm 0.83$ & $4.77 \pm 1.09$ & $P<0.12$ NS \\
\hline Circulates between groups & $4.36 \pm 1.20$ & $4.88 \pm 1.05$ & $P<0.31 \mathrm{NS}$ \\
\hline Redirects students & $3.36 \pm 1.12$ & $4.11 \pm 0.92$ & $P<0.12$ NS \\
\hline Fixed pins & $4.18 \pm 1.07$ & $3.66 \pm 1.22$ & $P<0.33 \mathrm{NS}$ \\
\hline
\end{tabular}

NS: Not significant, $P<0.05,{ }^{* *} P<0.01, P<0.001$. 
Table 16. Quality of component jurisdiction in encouraging pupils.

\begin{tabular}{|c|c|c|c|c|}
\hline & Average \pm e-t & Extended (Min-Max) & $\begin{array}{l}\text { Compared with the } \\
\text { standard value }\end{array}$ & $\begin{array}{l}\text { Level of mastery of the } \\
\text { indicator }\end{array}$ \\
\hline Jurisdiction of encouraging students & $4.22 \pm 0.42$ & $3.43-5.29$ & $P<0.031$ (Significant) & Well mastered \\
\hline
\end{tabular}

Table 17. Quality of component skill encouragement of students by level of qualification.

\begin{tabular}{ccc}
\hline & Average $\pm \mathrm{e}-\mathrm{t}$ & Comparison of mean \\
\hline Teacher (E2) & $3.96 \pm 0.27$ & $P<0.001$ (Significant) \\
Teacher (E1) & $4.53 \pm 0.36$ & \\
\hline
\end{tabular}

Table 18. Quality indicators of the component skill of encouraging students of all teachers.

\begin{tabular}{|c|c|c|c|c|}
\hline & Average $\pm \mathrm{e}-\mathrm{t}$ & $\begin{array}{l}\text { Extended } \\
\text { (Min-Max) }\end{array}$ & $\begin{array}{l}\text { Compared with the } \\
\text { standard value }\end{array}$ & $\begin{array}{l}\text { Level of mastery of the } \\
\text { indicator }\end{array}$ \\
\hline Encourages the student to correct itself & $5.05 \pm 1.05$ & $3-6$ & $P=0.001^{* * *}$ & Well Mastered \\
\hline Encourages students to help each & $3.80 \pm 1.05$ & $2-6$ & $P=0.40 \mathrm{NS}$ & Moderately Mastered \\
\hline Avoids negative reviews & $3.35 \pm 0.98$ & $2-5$ & $P=0.008^{* *}$ & Little Mastered \\
\hline Creates interaction between students & $3.60 \pm 0.88$ & $2-6$ & $P=0.057 \mathrm{NS}$ & Moderately Mastered \\
\hline stimulates students (Even the lowest) & $4.25 \pm 1.06$ & $2-6$ & $P=0.30 \mathrm{NS}$ & Moderately Mastered \\
\hline Encourages students by asking them personally & $4.65 \pm 1.08$ & $2-6$ & $P=0.015^{*}$ & Well Mastered \\
\hline Provides feeds back positive (well, yes. Voila...) & $4.85 \pm 0.93$ & $3-6$ & $P=0.001^{* * *}$ & Well Mastered \\
\hline
\end{tabular}

NS: Not significant, ${ }^{*} P<0.05,{ }^{* *} P<0.01 ;{ }^{* * *} P<0.001$.

mastered the incentive for the student to correct itself, made the giving of positive feeds back and encouragement by personal interrogation. The made to encourage students to help each other, made to encourage the interaction between students and the stimulation of students seem to be three indicators of encouraging pupils moderately mastered. However, it is noted that the made to avoid negative criticism is not mastered by SPE teachers studied.

2) Evaluation of the quality of ownership of various indicators on encouraging pupils to the level of qualification of PE teachers.

The analysis of the above-indicated in Table 19 and data on indicators that are on the encouragement of students by level of qualification of PE teachers, we concluded that among the seven indicators encouraging pupils are indifferent level five qualification PE teachers. We note respectively the indicator on the incentive for students to correct itself, by encouraging personal question, inciting students to help each other, the fact that create interaction between students as well as avoiding negative criticism. By cons we found that PE teachers (E1) better mastered the stimulation of students and giving positive feeds back the SPE teachers (E2).

\subsection{Component of Jurisdiction in Respect of Planning}

\subsubsection{Evaluation of Compliance with the General Planning}

1) Assessment of compliance with the planning of all teachers surveyed.

Statistical analysis values given in Table 20 indicates that the pedagogical frameworks observed moderately mastered the skill on the enforcement of planning previously designed.

2) Evaluation of compliance with planning the level of qualification of PE teachers studied.

The use of statistical values in Table 21 on the effect of varying skill levels of teachers on teaching skills relating to compliance with the planning has allowed us to infer that the degree of mastery of the latter is indifferent whatever academic graduation.

\subsubsection{Evaluation of the Quality of Ownership of Various Indicators Relating to Compliance with Planning}

1) Evaluation of the quality of ownership of various indicators relating to compliance with the planning of all 
Table 19. Quality indicators for the encouragement of students by level of qualification.

\begin{tabular}{cccc}
\hline & Average $\pm \mathrm{e}-\mathrm{t}$ & & \\
\hline Indicators & Teacher (E2) & Teacher (E1) & Comparison of mean \\
\hline Encouraging the student to correct itself & $4.90 \pm 1.13$ & $5.22 \pm 0.97$ & $P<0.52 \mathrm{NS}$ \\
Encouraging students to help each other & $3.90 \pm 1.04$ & $3.66 \pm 1.11$ & $P<0.62 \mathrm{NS}$ \\
Avoids negative reviews & $3 \pm 1$ & $3.77 \pm 0.83$ & $P<0.07 \mathrm{NS}$ \\
The fact create interaction between students & $3.54 \pm 0.93$ & $3.66 \pm 0.86$ & $P<0.76 \mathrm{NS}$ \\
Stimulating students (even the lowest) & $3.63 \pm 0.92$ & $5 \pm 0.70$ & $P<0.382^{* *}$ N.S \\
Encouraging students by asking them personally & $4.45 \pm 1.21$ & $4.88 \pm 0.92$ & $P<0.001^{* * *}$ \\
\hline The giving of feeds back positive & $4.27 \pm 0.64$ & $5.55 \pm 0.72$ & \\
\hline
\end{tabular}

NS: Not significant, $P<0.05,{ }^{* *} P<0.01,{ }^{* * *} P<0.001$.

Table 20. Quality of respect for the established planning.

\begin{tabular}{|c|c|c|c|c|}
\hline & Average $\pm \mathrm{e}-\mathrm{t}$ & $\begin{array}{c}\text { Extended } \\
\text { (Min-Max) }\end{array}$ & Compared with the standard value & degree of mastery \\
\hline Competence compliance planning & $3.96 \pm 0.61$ & $3.00-4.75$ & $P=0.78$ (Not significant) & Moderately mastered \\
\hline
\end{tabular}

Table 21. Quality planning in respect to the level of qualification.

\begin{tabular}{ccc}
\hline & Average $\pm \mathrm{e}-\mathrm{t}$ & Comparison of mean \\
\hline Teacher (E2) & $3.90 \pm 0.64$ & $P<0.68$ (Not significant) \\
\hline
\end{tabular}

teachers.

The use Table 22 has allowed us to conclude that the majority of teachers have mastered the observed compliance cyclic programming. Fixing the number of passes and the adaptation of the session in relation to unforeseen seem to be two indicators of compliance with planning moderately mastered. However, it should be noted that compliance with the time allotted for each situation is somewhat mastered by SPE teachers studied.

2) Evaluation of the quality of ownership of various indicators on the enforcement of planning based on the level of qualification of SPE teachers.

The analysis of the above-indicated in Table 23 bearing on indicators relating to compliance planning based on the level of qualification of teachers EPS data, we concluded that the provision of educational level cadres four component indicators compliance planning is indifferent if one takes into account the level of qualification of SPE teachers.

\section{Discussion}

The main purpose of our study is to decide on the quality of ownership of one of the professional skills teaching by SPE teachers having different skill levels. Indeed, the chosen jurisdiction is represented by the ability to drive learning situations. Such jurisdiction is composed of several components and indicators (behavioral, cognitive and pedagogical) and quality of acquisition would be greatly influenced by the academic degree obtained (Lessard and Schmidt, 2011).

In fact, the results obtained in this study shows us significant differences in the performance of teachers (E1) and (E2) level of competence in general and also control the level of some components of the above jurisdictionindicated as the accuracy of resources to which students have access to perform the learning, the organization of groups and encouraging students.

Indeed, we found that teachers (E2) develop sufficient skills to effectively manage the complexity of learning situations unlike teachers (E1) who have developed capacities to observe relevant aspects of teaching situations, to process and interpret effectively. This efficiency comes from the fact that these teachers are more likely to use several essential skills in piloting learning situations and to ensure an effective mode of supervision and keep 
Table 22. Quality indicators relating to compliance planning.

\begin{tabular}{|c|c|c|c|c|}
\hline & Average $\pm \mathrm{e}-\mathrm{t}$ & $\begin{array}{l}\text { Extended } \\
\text { (Min-Max) }\end{array}$ & $\begin{array}{l}\text { Compared with the } \\
\text { standard value }\end{array}$ & $\begin{array}{c}\text { Level of mastery of the } \\
\text { indicator }\end{array}$ \\
\hline Respect the cyclic programming & $4.65 \pm 0.98$ & $3-6$ & $P=0.008^{* *}$ & Well Mastered \\
\hline Sets the number of passes and repeat & $3.60 \pm 0.99$ & $2-5$ & $P=0.08 \mathrm{NS}$ & Moderately Mastered \\
\hline Respect the time allotted for each situation & $3.35 \pm 1.13$ & $2-6$ & $P=0.019^{*}$ & Little mastered \\
\hline Adapts the session compared to unforeseen & $4.25 \pm 0.85$ & $3-6$ & $P=0.20 \mathrm{NS}$ & Moderately Mastered \\
\hline
\end{tabular}

$P$ : Probability; NS: Not significant; ${ }^{*} P<0.05 ;{ }^{* *} P<0.01 ; P<0.001$.

Table 23. Quality indicators relating to compliance planning based on the level of qualification.

\begin{tabular}{|c|c|c|c|}
\hline \multicolumn{4}{|c|}{ Average $\pm \mathrm{e}-\mathrm{t}$} \\
\hline Indicators & Teacher (E2) & Teacher (E1) & Comparison of mean \\
\hline Respect for cyclic programming & $4.54 \pm 1.21$ & $4.77 \pm 0.66$ & $P<0.61 \mathrm{NS}$ \\
\hline Fixing the number of passes and repeat & $3.36 \pm 1.12$ & $3.88 \pm 0.78$ & $P<0.25 \mathrm{NS}$ \\
\hline Respect the time allotted for each situation & $3.36 \pm 1.02$ & $3.33 \pm 1.32$ & $P<0.95 \mathrm{NS}$ \\
\hline The adaptation of the meeting in relation to unforeseen & $4.36 \pm 1.02$ & $4.11 \pm 0.60$ & $P<0.52 \mathrm{NS}$ \\
\hline
\end{tabular}

NS: Not significant; $P<0.05 ; P<0.01 ; P<0.001$.

students in the task (Desbiens et al., 2009).

In reality, the results for the degree of mastery of the competency pilot shows that it is moderately mastered by all the teachers observed. What we have obtained as a result consistent with what has been suggested by the results of the authors (Le Boterf 1994; Ropé \& Tanguy, 1994; Scallon, 2004) which provides that the jurisdiction steering refers to the mobilization by the subject, a set of resources, attitudes, knowledge, knowledge of different types to meet a family of complex situations with maximum effectiveness and efficiency. Hence we can understand that this skill and quite complex and that teachers can not control it perfectly for several skills into play to succeed (Rey, 1996).

However, the ability to lead a class is primarily a socially defined competence. Excellence is specified differently depending on the history of recruitment, the nature and duration of university education. Three teaching models SPE stand (Ade et al., 2009) historically. These models seem to be in the definition of professional excellence given by the SPE teachers: the sports announcer, sports technician and engineer in teaching.

When asked teachers to define the most important skill to teach, the answers differ. They seem to be organized in a group setting rather human and relational qualities characterizing a good facilitator, a group characterizing knowledge and technical know-how specific to the technician and a group using resources more methodological analysis and reflection necessary for engineering teaching. The development also depends on skills training institutions and training modes (Amade-Escot, 1993).

Further analysis at the component level of the component control also shows that teachers (E1) and (E2) reveal difficulties in adequately explain the task to be performed using a language that does not support learning and complicates the situation for the student rather than facilitate understanding. Knowing that the main didactic function verbal instructions lies in clarifying the goal and sub-goals of the task (Gentile, 1972; Famose, 1983).

The student must know with utmost clarity the goal, the teacher realizes that very clearly. A first distinction can help to classify the skills depending on the degree of uncertainty in the sub-goals of the task: technical skills and strategic skills (Delignières et al., 1991) will be discussed. Goals and sub-goals are to some technical skills, uncertain for strategic skills.

On the other hand, interventions to specify the resources to which students have access to perform learning and greater participation are often ignored by PE teachers and more specifically among teachers (E2). These hardly intervene to give the student an indication for successful action. Indeed, teachers (E1) have been more effective than teachers (E2) in this category of intervention that it is important to raise awareness As students of their involvement in the task, the fact that they have improved and that the work done getting close to the desired goals. This is explained by the fact that students do not realize that they develop their skills (Archam- 
bault and Chouinard, 2005).

It is also pertinent to note that this component of the competence steering is quite important for successful learning situation, students are not able to master all in the same degree the different skills to interact appropriately, it is therefore necessary that the teacher helps them develop these skills by providing specific guidance for practice. The effectiveness of the teacher also reveals the need to make frequent reminders about the skills they want to acquire their students and encourage them when they apply (and Fallona, Richardson, 2001; Rosenberg \& Jackman, 2003).

Similarly, Bru et al. (2004) also highlighted the important role of verbal exchanges. While relying on the constructivist theory of Piaget, however it in away in that construction takes place through language, interacting with students. As regards the organization of groups, which is the third component of the competence steering statistical analyzes showed that this skill is moderately mastered by all PE teachers observed. Indeed teachers (E1) better mastered the setting of the competence relating to the organization of groups than those with a lower level, in the case of teachers (E2).

In addition, these pedagogical frameworks showed unavailable to students. Similarly, it was also found despite the clear marking of the land, are still vague directions to learners. For the teacher, the delimitation of workspaces educational materials, seeks to lead students to deal with specific areas, and determines their commitment to work in each workshop and space in the class. Opening certain areas, and reducing others, it builds the possibility of a quick and visual monitoring at the same time, he made clear to students in a roundabout way they are easy to spot if they are not at their instead (Vors \& Gal-Petitfaux, 2008).

In addition, it is worth noting the importance of spatial organization for SPE teachers as a condition propaedeutic school work. Nevertheless, it is important not to think that the work of the teacher is limited to the material organization, there is no "magic of the task". The teacher in his class regulates and intervenes with the hardware. And we must respect the spatial organization provided (Vors \& Gal-Petitfaux, 2008).

Add to what was previously mentioned, teachers should arrange their workplace according to specific physical structures and social organizations to organize their activities and those of students. The teaching of EPS, including "is not taught in places designed for educational purposes, but in sports facilities that meet the unique requirements of the regulations, practices and sporting events. So that these areas need to be do-mesticated by teachers who care and are rarely used as such. They shape according to their intentions. Whatever the discipline, there is always a stage in education, but it is much more apparent in physical education ” (Durand \& Veyrunes, 2005).

Thus, and according Tochan 1993 SPE teach is to arrange a scene work and deal with it to transmit knowledge. The act of transmission is performed on this stage that the teacher and landscape which in turn shapes its action, guide interventions, frame the nature of knowledge transmitted to students. Accordingly, the teacher inhabits his workspace as a stage. If the purpose of the activity of a teacher is not one of aesthetic production, it nevertheless remains true creative practice. In fact, the teacher is a composer: he is his stage work; there is space agency interaction with students; it is important and manipulate various objects to organize its operations in time and space; it leads and takes a meeting with an audience of students, he creates his posture, his gestures, his words, his intonations, like an actor on stage. Improvisation in particular is an essential skill in teaching (Tochon, 1993).

For his part, Yinger (1987) examines the common characteristics of improvisation acts in different practices such as traditional oral poetry, theater, music and everyday conversation. It demonstrates that these practices are consistent with the interactive benefits of the experienced teacher.

On the other hand, the analysis of the fourth component and indicators results also show that teachers (E2) were less intervention type encouragement than their counterparts maitrisards. In this regard, an effective teacher, qualified fair and equitable, that is the success of all students, not let them depreciate but rather encourage them to provide the necessary efforts so that they complete to the best of skills the task they have undertaken (Chouinard et al., 2005).

So in general, teachers encourage students to help each other, stimulate interaction between students and stimulate by cons they do not avoid negative feedback. Knowing that, the positive feedback is a key to student learning element. Bilodeau (1969) states that student performance is deteriorating by the absence of feedback. This fact and given the revelations Carreiro da Costa and Piéron (1990) argue that the effectiveness of the teacher takes the proportion of feedback issued and their appropriate characters, we are able to say that teachers have better skills encouragement to promote student learning. 
Also, it is noted that the results of our research show that teachers surveyed do not meet properly planning which is the last component of the driving skill, do not respect the time allotted for each situation, rarely fixed number of passes and not properly fit the session in relation to unforeseen. Teachers feel imprisoned in their planning. What can be explained by the absence of the concept of learning and teaching control situations teachings. In this regard, Johnson (1994) stated that the lack of skill of novice teachers to manage classes sometimes ends with possible problems of disciplines and less time devoted to learning caused by the loss of control of teacher. Thus, poor management led to the class that is generated by indiscipline inadequate interventions Teacher (Kounin, 1970).

However, Tardif et al. (1998) show that proper planning of teaching situations promotes student learning. It allows the teacher to anticipate how to organize the work of the group, drawing its attention to the material to see and activities happening in the classroom. These same authors also specify that planning means the adaptation of content to students' needs, clarifying expectations in terms of student behavior, organizing the educational environment that is to say the time, place, materials and resources, the choice of teaching strategies, the organization of learning activities, determining the sequence of activities and the choice of means of evaluation.

Durfour (2010) explained his part in its work, the problems in classroom management interventions fall inadequate teacher. It is for this reason that the effectiveness of the latter states and essentially requires that it should easily adapt to what is happening in the classroom, change its planning function of the progress of activities and the students' reactions deal with these events and learning situations (Archambault and Chouinard, 2003).

However, we must remember that Jonnaert et al. (2005) states that create the master teacher is not learning from another, it is the student who is responsible for the learning process by his behavior, operations, interventions or questions to this one. Finally, we must emphasize the fact that the art of teaching is to intervene on each student's learning process through meaningful and differentiated teaching procedures. To design interventions effectively, De Corte advocates the use of didaxologie, "an educational service of the learner, incorporating all scientific advances in learning and teaching” (Vigot, 1993).

\section{Conclusion}

The research for this study focused on determining the degree of mastery of the competency steering learning situations by the physical education teachers with differences in academic qualification.

Indeed, the analysis shows that four indicators for the explanation of the task are moderately mastered by all teachers studied i.e. using a pleasant and enthusiastic tone, the use of gestural demonstration, and the research to maintain eye gaze with students, and inviting the attention of students.

Nevertheless, three indicators are not mastered, we note respectively the indicator on the repetition of evil assimilated, verification of student understanding and use of plain language. However, the academic degree variable accounts for only indicator of the component relating to the fact of trying to maintain eye gaze with the students and that's where we found that teachers (E1) mastered it better than teachers of Type E2.

Teachers in their teaching practices, are concerned about the success of their students. We must act to clarify the paths to learning, specifying the particulars necessary for successful action. However, our study sample ignores completely this major component of competence, which is the fact to specify the resources how students have access to perform learning.

Indeed, teachers (E1) give more importance to it than teachers (E2). In addition, among the five indicators of competence precision resources surveyed, only one indicator is well mastered by all teachers studied, namely the use of space that responds to the number of students and the nature of activity. However, they moderately mastered the use of teaching materials available and use of the whistle and stopwatch. By cons, two indicators are not mastered, namely, the use of music and the media use. It should be noted that the level of qualification of $\mathrm{PE}$ teachers do not intervene for the five component indicators of competence in the accuracy of resources.

On the other hand, several authors such as Gal-Petitfaux (2008) emphasized the important role of the teacher in the delimitation of teaching spaces with materials, made to try to lead students to occupy specific areas, conditioning their commitment to work in each workshop and space in the class. Opening certain areas, and reducing others, it built the possibility of a quick and visual monitoring at the same time, he makes clear to students so that they are easily identifiable if they are not in their place. 
It is the organization of groups in space and time that our study population mastered the medium. Those with a qualification level (bac +4) mastered better component of competence regarding the organization of groups as having a level of qualification (Tray 2). In contrast, the study of indicators of this component allowed us to infer that all teachers have mastered the movement between groups when they have mastered the medium availability to students, markup field, the accuracy of directions, redirecting students and setting benchmarks. However, it should be noted that the variable level of qualification occurs only for marking the field and our results confirm that teachers (E1) is more careful during the delimitation of the teaching spaces that they counterpart (E2).

Finally, good planning teaching situations promote student to learn and allow the teacher to anticipate how to organize the work of the group, to attract attention on the subjects discussed and the activities taking place in the classroom. However, all teachers studied moderately mastered this skill component on compliance planning. This component is not affected by the variable level of qualification. Also, all indicators of this component are indifferent to this variable. Indeed, the SPE teacher have mastered the respect of the cyclic program, mastered medium fixing the number of passes and the adaptation of the session in relation to unplanned. By cons, they mastered little respect for the time allotted for each situation.

\section{References}

Adé, D., Veyrunes, P., Poizat, G. (2009). Analyse de l’activité des enseignants: Le rôle des objets dans la construction de l'activité interindividuelle en classe. Travail et Apprentissage, 3, 124-137.

Altet, M., Paquay. L., \& Perrenoud, Ph. (dir.) (2002). Formateurs d'enseignants. Quelle professionnalisation ? Bruxelles: De Boeck.

Amade-Escot, C. (2003). La gestion interactive du contrat didactique en volley-ball: Agencement des milieux et régulations du professeur. In C. Amade-Escot, (Ed.), Didactique de l'éducation physique: Etat des recherches (pp. 255-278). Paris: Editions Revue EPS.

Archambault, J. \& Chouinard, R. (2003). Vers une gestion éducative de la classe (2 éd.). Boucherville: Gaëtan Morin,.

Bouthier, D. (1986). Comparaison expérimentale des effets de différents modèles didactiques des sports collectifs. In EPS, contenus et didactique (pp. 85-89). Paris: SNEP.

Bru, M., Altet, M., \& Blanchard-Laville, C. (2004). A la recherche des processus caractéristiques des pratiques enseignantes dans leurs rapports aux apprentissages. Revue Française de Pédagogie, 148, 75-87. http://dx.doi.org/10.3406/rfp.2004.3251

Chouinard, R., Plouffe, C., \& Archambault, J. (2005). Le soutien de la motivation scolaire. In N. Desbiens, C. Lanaris, \& L. Massé (Dir), Les troubles des comportements à l'école: Prévention, évaluation et intervention (pp. 261-270). Québec: Gaétan Morin.

Delignières, D., Legros, P., \& Famose, J. P. (1991). Perception de l’effort et difficulté de la tâche. Science et Motricité, 13, $14-18$

Desbiens, J.-F., Borges, C., \& Spallanzani, C. (2009). Investir dans la formation des personnes enseignantes associées pour faire du stage en enseignement un instrument de développement professionnel. Éducation et Francophonie, 37, 6-27. http://dx.doi.org/10.7202/037650ar

Durand, M., \& Veyrunes, P. (2005). L'analyse de l'activité des enseignants dans le cadre d'un programme d'ergonomie formation. In Y. Lenoir (Ed.), Les pratiques enseignantes: Analyse des données empiriques. Les Dossiers des Sciences de l'Education, 14, 47-60.

Famose, J. P. (1983). Stratégies pédagogiques, tâches motrices et traitement de l'information. In Savoirs professionnels et curriculum de formation (pp. 83-107). Laval: Les presses universitaires Laval.

Gentile, A. M. (1972). A Working Model of Skill Acquisition with Application to Teaching. Quest, 17, 3-23. http://dx.doi.org/10.1080/00336297.1972.10519717

Jonnaert, Ph., Barrette, J., Boufrahi, S., \& Masciotra, D. (2005). Contribution critique au développement des programmes d'études: Compétences, constructivisme et interdisciplinarité. Revue des sciences de l'éducation, 30, 667-696. http://dx.doi.org/10.7202/012087ar

Kounin, J. S. (1970). Discipline and Group Management in Classroom. New York, NY: Holt, Rinehart and Winston.

Le Boterf, G. (1994). De la compétence. Essai sur un attracteur étrange. Paris: Les Éditions d’organisation.

Lebrun, N., \& Wood, J. M. (2002). Performance, réussite, succès: Enjeux et défis de taille dan les réformes des programmes scolaires du primaire au Québec. In O. Bouab, (Ed.), actes du groupe de didactique des Sciences de Marrakech (Marrakech, 22, 23 et 24 avril 2002). Marrakech: Université Cadi Ayyad, Maroc.

Perrenoud, Ph. (1993). L’organisation, l’efficacité et le changement, réalités construites par les acteurs. Education et Re- 
cherche, 2, 197-217.

Perrenoud, Ph. (1994a). Compétences, habitus et savoirs professionnels. European Journal of Teacher Education, 17 , 45-48. http://dx.doi.org/10.1080/0261976940170108

Perrenoud, Ph. (1994b). La formation des enseignants entre théorie et pratique. Paris: L'Harmattan.

Rey, B. (1996). Les compétences transversales en question. Paris: ESF.

Ropé, F., \& Tanguy, L. (1994). Savoirs et compétences. De l'usage de ces notions dans l'école et l'entreprise. Paris: L'Harmattan.

Rosenberg, M. S., \& Jackman, L. A. ( 2003). Development, Implementation, and Sustainability of Comprehensive SchoolWide Behavior Management Systems. Intervention in School and Clinic, 39, 10-21. http://dx.doi.org/10.1177/10534512030390010201

Roux-Perez, T. (2005). L’identité professionnelle des enseignants d’EPS: Entre valeurs partagées et interprétations singulières. Revue STAPS, 63, 75-88. http://dx.doi.org/10.3917/sta.063.0075

Scallon, G. (2004). L'évaluation des apprentissages dans une approche par compétences. Saint-Laurent (Montréal): Éditions du renouveau pédagogique.

Tardif, M. (1993). Les fondements de l'éducation contemporaine et le conflit des rationalités. Revue des sciences de l'éducation, 20, 802-803.

Tardif, M., Lessard, C., \& Gauthier, C. (1998). Formation des maîtres et contextes sociaux. Perspectives internationales. Paris: Presses universitaires de France.

Theureau, J. (2000). Anthropologie cognitive et analyse des competences. In J. M. Barbier (Ed.), L'analyse de la singularité de l'action (pp. 171-211). Paris: PUF.

Tochon, F. V. (1993). L'enseignant expert. Paris: Nathan.

Ubaldi J.-L. (2006). Débuter dans l'enseignement. Recherche et formation, 56, 162-166.

Vergnaud, G. (1993). Quelques problèmes théoriques de la didactique à partir d’un exemple: Les structures additives. In S. Joshua, \& J. J. Dupin (Eds.), Introduction à la didactique des sciences et des mathématiques. Paris: PUF.

Vors, O., \& Gal-Petitfaux, N. (2009). Construire une activité collective de travail dans une classe d’EPS en 'Réseau ambition réussite': Entre masquage et ostentation. eJRIEPS, 18, 156-177.

Yinger, J. R. (1987). Learning the Language of Practice. Curriculum Inquiry, 17, 293-318.

http://dx.doi.org/10.2307/1179695 
Scientific Research Publishing (SCIRP) is one of the largest Open Access journal publishers. It is currently publishing more than 200 open access, online, peer-reviewed journals covering a wide range of academic disciplines. SCIRP serves the worldwide academic communities and contributes to the progress and application of science with its publication.

Other selected journals from SCIRP are listed as below. Submit your manuscript to us via either submit@scirp.org or Online Submission Portal.
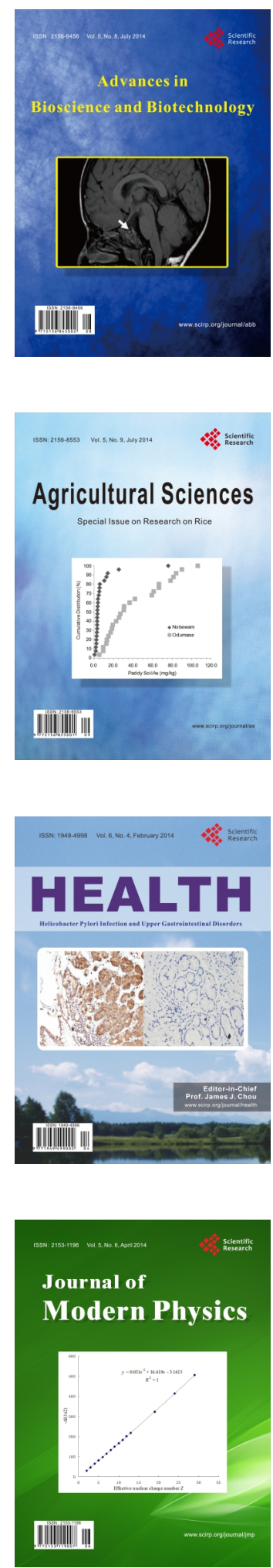
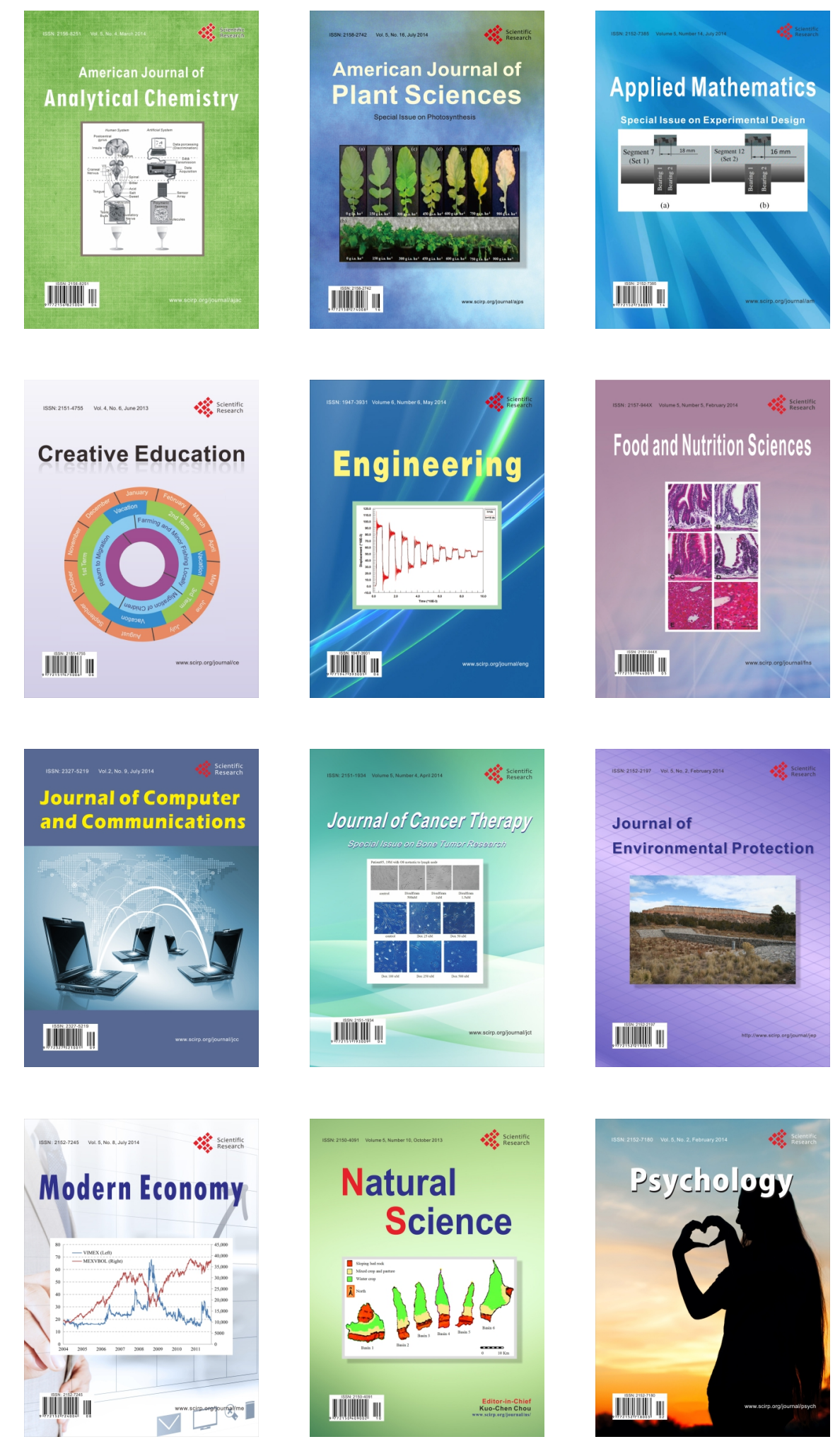